\section{Leddskade ved revmatoid artritt}

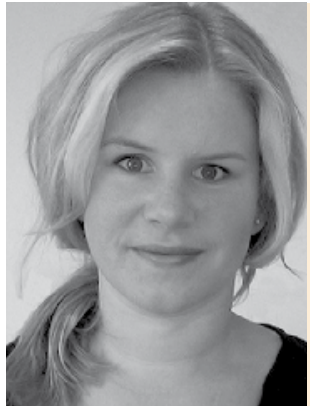

Siri Lillegraven

Siri Lillegraven ved Institutt for klinisk medisin, Universitet i Oslo forsvarte den 12. november 2013 sin avhandling for graden ph.d.:

\section{Joint damage in rheumatoid arthritis}

Siri Lillegraven har i sitt doktorgradsarbeid sett på hvordan forskjellige sykdomsmarkører kan bidra til å predikere hvilke RA-pasienter som utvikler leddskade.

Blant revmatologer i Norge har det blitt vanlig å bruke ultralyd som en del av undersøkelsen av pasienter med artrittsykdommer. Ultralyd gir et bedre bilde av hvorvidt leddene er betent enn klinisk undersøkelse alene, men det var likevel lenge usikkert, hvorvidt funnene også hadde prognostisk verdi for sykdomsutviklingen.

Lillegraven og medarbeidere viste i en studie av norske pasienter med ny oppstått RA at selv en relativt enkel ultralydundersøkelse kan hjelpe med å identifisere pasienter med økt risiko for leddskade. 